\title{
Piscinoodinium pillulare (SCHÄPERCLAUS, 1954) LOM, 1981 (DINOFLAGELLIDA) INFECTION IN CULTIVATED FRESHWATER FISH FROM THE NORTHEAST REGION OF SÃO PAULO STATE, BRAZIL. PARASITOLOGICAL AND PATHOLOGICAL ASPECTS
}

\author{
MARTINS, M. L., ${ }^{1}$ MORAES, J. R. E., ${ }^{2}$ ANDRADE, P. M., ${ }^{1}$ SCHALCH, S. H. C. ${ }^{1}$ and \\ MORAES, F. R. ${ }^{1,2}$ \\ ${ }^{1}$ Centro de Aqüicultura, Unesp, Via Prof. Paulo Donato Castellani, km 5, CEP 14870-000, Jaboticabal, SP, Brazil \\ ${ }^{2}$ Departamento de Patologia Veterinária, FCAV, Unesp, Via Prof. Paulo Donato Castellani, km 5, CEP 14870-000, \\ Jaboticabal, SP, Brazil \\ Correspondence to: Dr. Maurício L. Martins, Centro de Aqüicultura, Unesp, Via Prof. Paulo Donato Castellani, \\ km 5, CEP 14870-000, Jaboticabal, SP, Brazil, e-mail: mlaterca@caunesp.unesp.br \\ Received June 13, 2000 - Accepted November 28, 2000 - Distributed November 30, 2001
}

(With 5 figures)

\begin{abstract}
The Aquaculture Center of Unesp, Jaboticabal, SP, Brazil, received fishes for diagnosis from fish farmers reporting fish crowding at pond edges and in water inlets. Fifty-three out of 194 cases showed round to oval, immobile whitish structures, measuring up to $162 \mu \mathrm{m}$ diameter, identified as the dinoflagellate Piscinoodinium pillulare. In 34 diagnosed cases the parasites were present in the gills, in 2 on body surface, and 9 in both. Thirty-one out of 53 were tambacu hybrids hosts; 7, Piaractus mesopotamicus; 6, Colossoma macropomum; 5, Leporinus macrocephalus; 3, Oreochromis niloticus; and 1, Prochilodus lineatus. Fish showed increased mucous production on body surface and gills, while ecchymosis in the caudal peduncle and operculum was present. The gills also showed paleness, congestion, and petechiae. Histopathology presented a great number of trophonts situated between secondary lamellae, fixed to or detached from the epithelium. Primary lamellae presented interstitial hemorrhages, severe hyperplasia of the epithelium, goblet cells, and mononuclear infiltrates. The present work is the first report of $P$. pillulare in Brazil and emphasizes the importance of this dinoflagellate which caused significant economic losses from 1995 through 1997.
\end{abstract}

Key words: Piscinoodinium pillulare, morphology, pathology, cultivated fish, Brazil.

\section{RESUMO}

Infecção por Piscinoodinium pillulare (Schäperclaus, 1954) Lom, 1981 (Dinoflagellida) em peixes de água doce cultivados na região Nordeste do Estado de São Paulo, Brasil. Aspectos parasitológicos e patológicos

O Centro de Aqüicultura, Unesp, Jaboticabal, SP, Brasil, recebeu peixes para diagnose, os quais apresentavam aglomeração nas bordas dos viveiros e na entrada da água. Dos 194 casos diagnosticados, 53 apresentavam estruturas brancas circulares ou ovais, imóveis, medindo $162 \mu \mathrm{m}$ de diâmetro, identificadas como o dinoflagelado Piscinoodinium pillulare. Em 34 casos, os parasitos estavam presentes nas brânquias, em 2 casos, no corpo e em 9 casos, em ambos. Dos 53 casos observados, 31 eram o híbrido tambacu; 7, o Piaractus mesopotamicus; 6, o Colossoma macropomum; 5, o Leporinus macrocephalus; 3, o Oreochromis niloticus; e 1, o Prochilodus lineatus. Os peixes apresentaram aumento da produção de muco no corpo e nas brânquias e equimoses no pedúnculo caudal e nos opérculos. As brânquias também apresentaram palidez, congestão e petéquias. A histopatologia revelou a presença de grande número de trofontes situados entre as lamelas secundárias, fixados ou não ao epitélio. As lamelas primárias 
mostraram hemorragias intersticiais, severa hiperplasia do epitélio e das células caliciformes e infiltrado inflamatório. O presente trabalho é o primeiro relato de P. pillulare no Brasil e enfatiza a importância dos dinoflagelados, que causaram significativas perdas econômicas entre 1995 e 1997.

Palavras-chave: Piscinoodinium pillulare, morfologia, patologia, peixe cultivado, Brasil.

\section{INTRODUCTION}

Dinoflagellates may be responsible for lethal diseases in marine fishes (Brown, 1934; Brown \& Hovasse, 1946; Noga et al., 1991; Smith et al., 1994; Quod et al., 1994). The first dinoflagellate parasite recorded in a fish host was Oodinium ocellatum (Brown, 1931). Nigrelli (1936) described morphology, cytology, and life cycle of $O$. ocellatum. Jacobs (1946) and Lucký (1970) reported the occurrence of $O$. limneticum and $O$. pillularis in aquarium fishes, while Williams Jr. (1972) observed $O$. cyprinodontum in the gills of Fundulus similis. Later, on, Lom (1981) proposed a new genus Piscinoodinium and chose Oodinium Chatton, 1912 genus as a synonym. Since then, Amyloodinium genus has been reported to have infected marine fishes, and Piscinoodinium genus to have infected freshwater fishes. The parasite was observed in the gills of Oreochromis niloticus, Sarotherodon galilaeus, and Clarias sp., from Kainji Lake, Nigeria (Okaeme \& Okojie, 1989). Moreover, the presence of $P$. pillulare in Malaysia caused mortality by inducing hyperplastic gills and obstruction of the respiratory surface (Shaharom-Harrison et al., 1990).

Until now, observations related to the occurrence of and infection with this parasite were unknown in Brazil. In the present work, the authors describe histopathological and morphological aspects of $P$. pillulare infection in cultivated fishes from the Northeast region of São Paulo State.

\section{MATERIAL AND METHODS}

From 1995 to 1997, 265 fishes were examined after necropsy at the Laboratory Aquatic Organisms Pathology at the Aquaculture Center, Unesp, Jaboticabal, São Paulo State, Brazil. Water quality was measured with a $\mathrm{pH}$-meter, a conductivimeter (Corning), dissolved oxygen with portable oxymeter (Hach), and water temperature with a mercury bulb thermometer. To search for parasites, the body surface was scraped from tail to head and pieces of gill 2-3 $\mathrm{mm}$ in diameter were mounted between glass microscope slide coverslips for microscopical observation. Bacteriological and fungal examinations were carried out according to Austin \& Austin (1987) and Martins $\&$ Machado (1994). Parasites found were stained with lugol solution for detecting amyloid granules. A camara lucida was used to draw 39 parasite specimens. All measurements taken were transformed into mean values and are shown with their respective change intervals. For scanning electron microscopy, the infected gill filaments were excised and fixed at room temperature in a 3\% glutaraldehyde solution in a $0.1 \mathrm{M}$ phosphate buffer ( $\mathrm{pH}$ 7.4). Afterwards, they were dehydrated with serial concentrations of acetone, dried with $\mathrm{CO}_{2}$, assembled, and coated with $20 \mathrm{~nm}$ gold paladium. Coated filaments were examined with a JEOL JSM-25-S2 microscope. Parasitized tissues were fixed in $10 \%$ buffered formalin and embedded in a paraffin block. Tissue sections 6 $\mu \mathrm{m}$ thick were cut and stained with haematoxilineosin for histopathological analysis.

\section{RESULTS}

The ponds where the fishes originated were situated in Barretos, Barrinha, Cravinhos, Franca, Guariba, Jaboticabal, Sertãozinho, Taiaçu, Taiúva, and Taquaral with 240 to $22,000 \mathrm{~m}^{2}$ of area with 1 to 8 fish $/ \mathrm{m}^{2}$ stocking density. Water quality showed $\mathrm{pH}$ $7.8 \pm 0.5$ (6.9 to 8.3 ), electric conductivity $136.0 \pm$ $48.1 \mu \mathrm{S} / \mathrm{cm}$ (29 to 205 ), dissolved oxygen $4.2 \pm 1.3$ (2.7 to 7.0), and water temperature 17 to $24^{\circ} \mathrm{C}$.

It had been reported that fish generally gathered near the pond edges or near the water inlets. Feeding activity decreased because of appetite loss; fish became lethargic, and swam erratically with loss of equilibrium. Mortality progressively increased. According to the farmers, fish ponds were rarely cleaned. In three cases, chicken bowels were fed to the fish.

From January 1995 to August 1997, fish mortality caused by dinoflagellates resulted in 23,000 
dead fish, 3,000 of which died in the period of May 1 to 15,1996 . In the same month, 4,000 fishes died in 24 hours at just one fish farm. One hundred ninetyfour cases of a total of 265 occurred during the cold season, from May to August, when the water temperature ranged between 17 and $24^{\circ} \mathrm{C}$.

Fifty-three cases of a total of 194, showed round to oval, immobile, whitish structures on gills and body surface, measuring up to $162 \mu \mathrm{m}$ in diameter. Of these, 34 were on the gills, 2 on the body surface, and 9 on both. Thirty-one out of 53 diagnosed cases occurred in a tambacu hybrid (Colossoma macropomum female $\mathrm{x}$ Piaractus mesopotamicus male) of 5.0 to $36.0 \mathrm{~cm}$ length; 7 (15.5\%) in pacu, Piaractus mesopotamicus Holmberg, 1887 of 5.0 to $28.5 \mathrm{~cm}$; six $(13.3 \%)$ in tambaqui, Colossoma macropomum Cuvier, 1818 of 5.0 to $18.0 \mathrm{~cm} ; 5$ (11.1\%) in piauçu, Leporinus macrocephalus Garavello and Britski, 1988 of 26.0 to $31.0 \mathrm{~cm}$; three $(6.6 \%)$ in tilápia, Oreochromis niloticus Trewavas, 1983 of 15.0 to 26.0 $\mathrm{cm}$ and $1(2.2 \%)$ in curimbatá, Prochilodus lineatus Steindachner, 1881 of $42.0 \mathrm{~cm}$.

Of all examined fish, tambacu hybrid showed $61.3 \%$ mortality, with 4,000 fish dying in just one day, and 11,000 in one fish farm. The P. mesopotamicus showed $42.8 \%$ mortality, C. macropomum $40 \%$, and $O$. niloticus and L. macrocephalus $33.3 \%$. Secondary infections with myxobacteria and Saprolegnia sp. on the body surface were also recorded.

\section{Parasitology}

Immobile, round to oval whitish structures on the gills and body surface of infected fish were observed. Amyloid granules in the parasites were stained by Lugol's solution. Parasite measurements

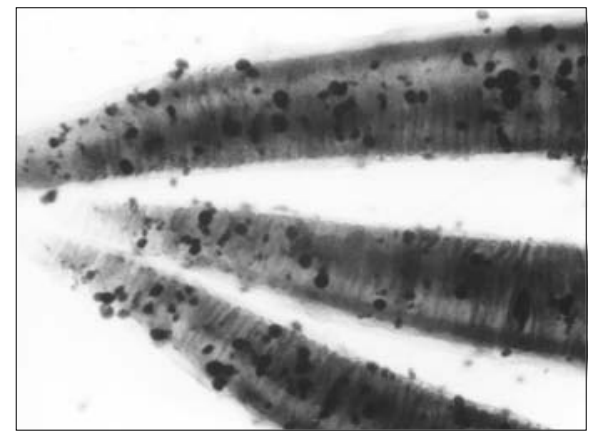

Fig. 1 - Wet mount of gill filament infected by $P$. pillulare. Tambacu hybrid $(40 \mathrm{x})$. were as follows: $102.7 \mu \mathrm{m}$ (62 to 162) in diameter (Fig. 1); in the basal region of the parasites an attachment disc was seen measuring $38.6 \mu \mathrm{m}$ (24 to 52) diameter; the cell of the attached trophont was pyriform or sac-like (Lom \& Schubert, 1983) measuring $47.7 \mu \mathrm{m}$ (36 to 70 ) in length and 33.5 $\mu \mathrm{m}$ (22 to 48) in width; the basal end was narrow, measuring $15.1 \mu \mathrm{m}$ (10 to 20 ). Pyriform cells were observed in large number on the gills of parasitized fish. A short structure extending from the basal end, measuring $21.4 \mu \mathrm{m}$ in length, was observed. The parasite was identified as the dinoflagellate Piscinoodinium pillulare.

Scanning electron microscopy showed trophonts attached to the gill epithelium in different developmental stages (Figs. 2 and 3).

\section{Structural changes}

On the body surface, increase in mucous production, scalelessness, suffusion, ecchymosis, petechiae, and small ulcers were observed. The gills also presented increase of mucous production besides epithelial hyperplasia, suffusion, petechiae, congestion, edema, and brownish areas (Table 1). Histopathology showed a great number of trophonts present in the secondary lamellae, sometimes with rhizocysts embedded in the epithelium which penetrated firmly into the epithelial cells. Degeneration and focal epithelial necrosis were observed. The primary lamellae showed congestion, subepithelial edema, focal interstitial hemorrhages, severe hyperplasia of epithelial and goblet cells, and inflammatory cells. The secondary lamellae were fused because of a hyperplastic process that formed cavities in which the parasites were present (Fig. 4).

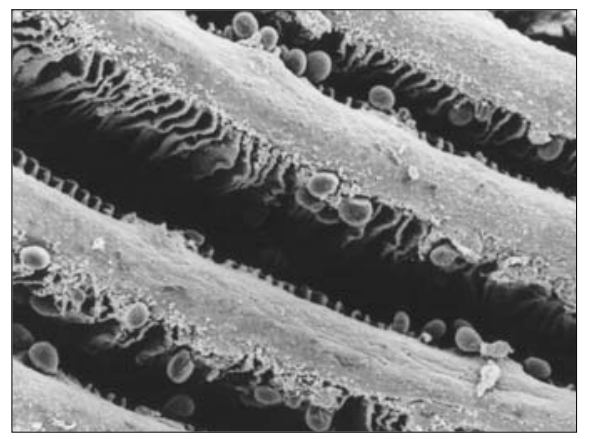

Fig. 2 - Scanning electron microscopy of gill filament infected by $P$. pillulare. Severe infection in tambacu hybrid (SEM $100 \mathrm{x}$ ). 


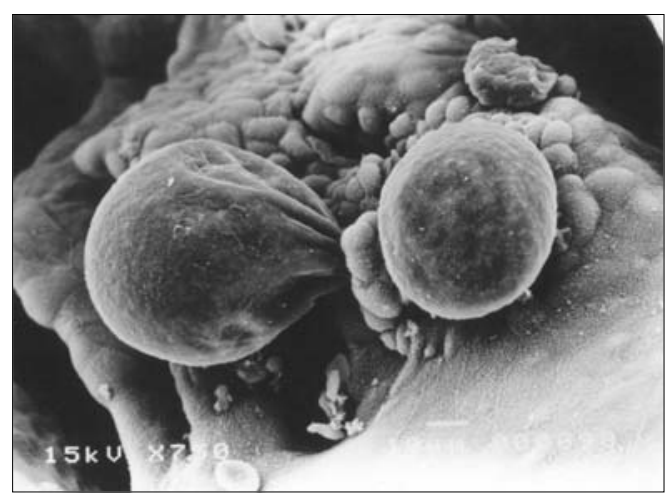

Fig. 3 - Scanning electron microscopy of trophont attached to the gill filament of tambacu hybrid (SEM $750 \mathrm{x}$ ).

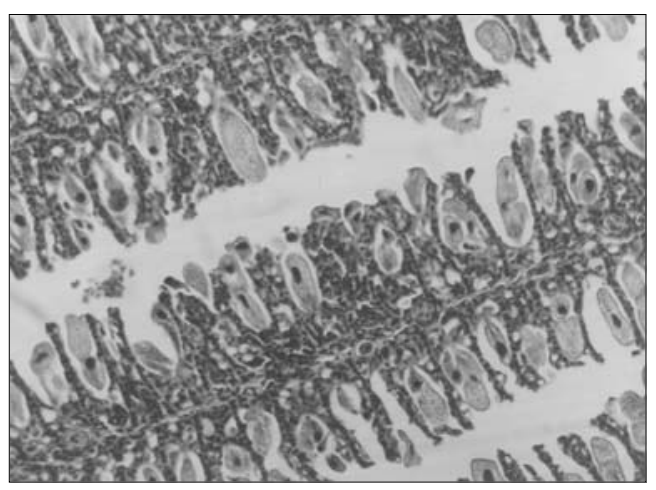

Fig. 4 - Parasitic trophonts of $P$. pillulare attached to the gill filament of tambacu hybrid (HE $150 \mathrm{x}$ ).

TABLE 1

Macroscopical lesions of Brazilian fish infected with Piscinoodinium pillulare.

\begin{tabular}{|c|c|c|}
\hline Fish species & Body surface & Gills \\
\hline Tambacu hybrid & $\begin{array}{c}\text { increase of mucous production, } \\
\text { scalelessness of epithelium, } \\
\text { suffusion on the } \\
\text { operculum and caudal peduncle }\end{array}$ & $\begin{array}{c}\text { paleness, increase of mucous production, } \\
\text { congestion, } \\
\text { petechiae, hyperplasia }\end{array}$ \\
\hline P. mesopotamicus & $\begin{array}{c}\text { suffusion, } \\
\text { small ulcers }\end{array}$ & $\begin{array}{c}\text { increase of mucous } \\
\text { production, edema, petechiae }\end{array}$ \\
\hline C. macropomum & scalelessness of epithelium & tissue with brownish color \\
\hline L. macrocephalus & scaleness, suffusion & suffusion \\
\hline O. niloticus & petechiae, ecchymosis & \\
\hline P. lineatus &
\end{tabular}

In addition, the extension of the hyperplastic process of the epithelial cells filled all interlamellar the space. These epithelium masses obstructed the respiratory surface of the gills (Fig. 5).

\section{DISCUSSION}

The present work showed the nonspecificity of $P$. pillulare that infects a great number of fish species in different regions of São Paulo State. High mortality caused by severe infection related to lack of cleaning of fish ponds; much organic matter as well as overcrowding were observed. These facts contributed to significant economic losses. Similar parasitosis associated with high levels of organic matter was described by Shaharom-Harrison et al. (1990) in Puntius gonionotus. The addition of chicken bowels to the fish diet, over population, and great quantity of food were the main causes of decreasing water quality, favoring parasitic reproduction (Martins, 1998) as observed in the present work.

Of the cases diagnosed, $73.3 \%$ occurred from May to August, demonstrating high fish susceptibility to parasites in the cold season when water temperature ranged from 17 to $24^{\circ} \mathrm{C}$. Temperatures below $24^{\circ} \mathrm{C}$ or above $31.5^{\circ} \mathrm{C}$ have contributed to mortality, according to Shaharom-Harrison et al. (1990).

This fact is probably related to better conditions for parasite reproduction and fish resistance decrease caused by stress. Temperatures below $10^{\circ} \mathrm{C}$ inhibit inflammatory response in ectothermic animals and cause high susceptibility to infections (Bisset, 1948 cited by Finn \& Nielsen, 1971; Dias \& Sinhorini, 1991; Matushima \& Mariano, 1996). 


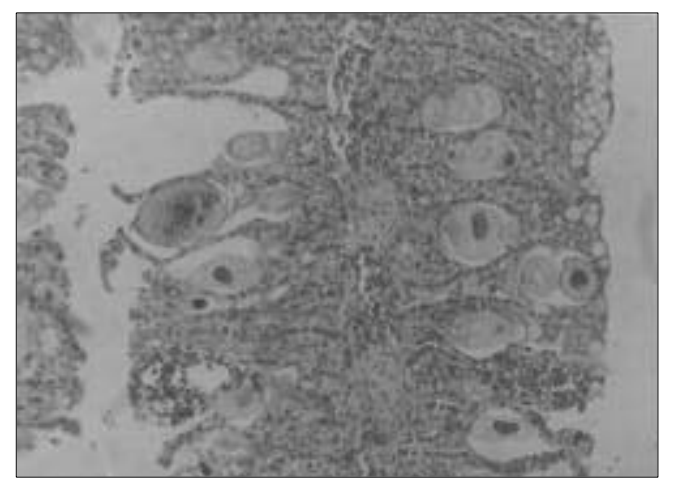

Fig. 5 - Infection with $P$. pillulare. Note severe hyperplasia with complete obstruction of the respiratory surfaces and haemorrhages (arrow). Tambacu hybrid (HE $300 \mathrm{x}$ ).

Mortality rate was higher in the hybrid tambacu than P. mesopotamicus and C. macropomum. However, tambacu and P. mesopotamicus were the most cultivated fishes in the fish farms.

Severe infections with $P$. pillulare in $P$. gonionotus cultivated in Malaysia from January 1986 through December 1987 were reported by Shaharom-Harrison et al. (1990). Some authors observed loss of appetite, lethargy, and agglomeration below the water surface (Siti \& Rokiah, 1988; Shaharom-Harrison et al., 1990), corroborating the present observations. Histopathological changes described in Brazilian cultivated fish were the same as those found by Brown (1934), Jacobs (1946), Lucký (1970), Cheung et al. (1981a), and Shaharom-Harrison et al. (1990) although the geographic region and breed of fish were different.

These lesions initiate a hyperplastic and edematous process in the gills causing changes in the gas and ion interchange surface with consequences for the fish metabolism (Martins \& Romero, 1996).

From January 1995 to July 1997, 20\% of the cases showed the dinoflagellate $P$. pillulare as the etiological agent. An attachment disc and rhizocysts inserted in the epithelial cells of the host (Lom, 1981) and the presence of amyloid granules (Jacobs, 1946) were used for identification. A flagellate structure situated in the basal extremity of the parasites was observed in just one case in this work, as was also reported by Lom \& Schubert (1983). According to Lom $(1977,1981)$, rhizocyst characteristics, their penetration into the host cells, and presence of chloroplasts constitute the main characteristics of the genus Piscinoodinium in freshwater fishes.

Nigrelli (1936) described various stages of the life cycle of $O$. ocellatum. When parasites are collected from the gills, rhyzocists and flagella retract. For this reason good observation of such structures was not possible in wet mounts. With the aid of scanning electronic microscopy, Cheung et al. (1981b) observed a severe epithelial irritation with hyperplastic reaction caused by $O$. ocellatum in the gills of Zebrassoma flavescens. These changes provoked increased mucous production and fusion of the lamellae. High organic matter content, low oxygen level, and overcrowding favoured parasite proliferation, causing stress and increasing susceptibility of fish to parasitism.

In conclusion, the present work is the first in Brazil that emphasizes the significance of dinoflagellates in cultivated fishes. The authors add that prophylaxis and water quality are essential factors in management of fish culture.

Acknowledgments - We would like to thank Drs. Waldener Garutti and Francisco L. Neto (Zoology Department, IBILCE, São José do Rio Preto, SP, Brazil) for identification of fish; Francisca A. Ardisson and Maria I. Y. de Campos for technical aid (Veterinary Pathology, Unesp, Jaboticabal, SP); Dr. Jaime M. dos Santos and Claudia A. Rodrigues for Scanning Electron Microscopy (Electron Microscopy, Unesp, Jaboticabal, SP); Gastão F. A. T. Reis, Paula C. B. Rezende (Immunediagnostic Laboratory, CPPAR - Animal Health Research Center, Unesp, Jaboticabal, SP) and Mariana C. Petric (Animal Pathology, Unesp, Jaboticabal, SP) for correction of translated manuscript.

\section{REFERENCES}

AUSTIN, B. \& AUSTIN, D. A., 1987, Bacterial Fish Pathogens: disease in farmed and wild fish. John Wiley \& Sons, New York, 364p.

BROWN, E. M., 1931, Note on a new species of dinoflagellate from the gill and epidermis of marine fishes. Proc. Zool. Soc. London, 1: 345-346.

BROWN, E. M., 1934, On Oodinium ocellatum Brown, a parasitic dinoflagellate causing epidemic diseases in marine fish. Proc. Zool. Soc. London, 2: 583-607. 
BROWN, E. M. \& HOVASSE, R., 1946, Amyloodinium ocellatum (Brown) a peridinian parasitic on marine fishes. A complementary study. Proc. Zool. Soc. London, 116: 33-46.

CHEUNG, P. J., NIGRELLI, R. F. \& RUGGIERI, G. D., 1981a, Oodinium ocellatum (Brown, 1931) (Dinoflagellata) in the kidney and internal tissues of pork fish, Anisotremus virginicus (L.). J. Fish Dis., 4: 523-525.

CHEUNG, P. J., NIGRELLI, R. F. \& RUGGIERI, G. D., 1981b, Development of Oodinium ocellatum (Dinoflagellida): a Scanning Electron Microscopic study. Trans. Am. Micros. Soc., 100(4): 415-420.

DIAS, J. L. C. \& SINHORINI, I. L., 1991, Qualitative evaluation of the inflammatory response modulated by temperature in tadpoles of Rana catesbeiana. Ci. e Cult., 43(4): 304-306.

FINN, J. P. \& NIELSEN, N. O., 1971, The effect of temperature variation on the inflammatory response of rainbow trout. J. Pathol., 105: 257-268.

JACOBS, D. L., 1946, A new parasitic dinoflagellate from freshwater fish. Trans. Am. Microsc. Soc., 65(1): 1-17.

LOM, J., 1977, Mode of attachment to the host in a dinoflagellate parasite of freshwater fishes. J. Protozool., 24(Suppl. I): 16a.

LOM, J., 1981, Fish invading dinoflagellates: a synopsis of existing and newly proposed genera. Folia Parasitol., 28: 3-11.

LOM, J. \& SCHUBERT, G., 1983, Ultrastructural study of Piscinoodinium pillulare (Schaperclaus, 1954) Lom 1981, with special emphasis on its attachment to the fish host. J. Fish Dis., 6: 411-428.

LUCKÝ, Z., 1970, Pathological changes with oodiniosis of aquarium fish. Acta Veterinaria (Brno), 39(Suppl. I): 6773.

MARTINS, M. L. \& MACHADO, J. O., 1994, Inoculação experimental de suspensão bacteriana e fúngica em alevinos de carpa, Cyprinus carpio L., 1758. Ars Veterinaria, 10(1): 65-69.

MARTINS, M. L. \& ROMERO, N. G., 1996, Efectos del parasitismo sobre el tejido branquial en peces cultivados: estudio parasitológico e histopatológico. Rev. Bras. Zool., 13(2): 489-500.
MARTINS, M. L., 1998, Doenças Infecciosas e Parasitárias de Peixes. Boletim Técnico Caunesp, n. 3, 2. ed. (ed. By Funep), Jaboticabal, SP, Brasil, 66p.

MATUSHIMA, E. R. \& MARIANO, M., 1996, Kinetics of the inflammatory reaction induced by carrageenin in the swimbladder of Oreochromis niloticus (Nile Tilapia). Braz. J. Vet. Res. Anim. Sci., 33(1): 5-10.

NIGRELLI, R. F., 1936, The morphology, cytology and lifehistory of Oodinium ocellatum Brown, a dinoflagellate parasite on marine fishes. Zoologica, 21: 129-164.

NOGA, E. J., SMITH, S. A. \& LANDSBERG, J. A., 1991, Amyloodiniosis in cultured hybrid striped bass (Morone saxatilis $\times M$. chrysops) in North Carolina. J. Aquat. Anim. Health, 3(4): 294-297.

OKAEME, A. N. \& OKOJIE, P., 1989, Parasites and diseases of feral Oreochromis niloticus, Sarotherodon galilaeus and Clarias sp. of Lake Kainji. Ann. Rep. Nat. Inst. Freshwater Fish. Res. Nigeria, pp. 41-44.

QUOD, J. P., BOURDEAU, P., TURQUET, J. \& GUIGNARD, A., 1994, Ciguater French overseas territories: epidemiological and pathophysiological aspects. Rec. Med. Vet., 170(2-3): 141-146.

SHAHAROM-HARRISON, F. M., ANDERSON, I. G., SITI, A. Z., SHAZILI, N. A. M., ANG, K. J. \& AZMI, T. I., 1990, Epizootics of Malaysian cultured freshwater pond fishes by Piscinoodinium pilullare. Aquaculture, 86: 127138.

SITI, A. Z. \& ROKIAH, L. A., 1988, Behavioral and morphological characteristics in Puntius gonionotus (Bleecker) with Piscinoodinium pillulare infestation. Proc. 11 th, Ann. Conf. Mal. Soc. Anim. Prod., 11: 69-72.

SMITH, S. A., LEVY, M. G. \& NOGA, E. J., 1994, Detection of anti-Amyloodinium ocellatum antibody from cultured hybrid striped bass (Morone saxatilis $\times$ M. chrysops) during na epizootic of amyloodiniosis. J. Aquat. Anim. Health, 6(1): 79-81.

WILLIAMS JR., E. H., 1972, Oodinium cyprinodontum Lawler (Dinoflagellida) on Fundulus similis (Baird and Girard) and Cyprinodon variegatus Lacepede from the Gulf of Mexico. Alabama Mar. Res. Bull., 8: 32-33. 